\title{
Impact of government intervention in the housing market: evidence from the housing purchase restriction policy in China
}

Article

Accepted Version

Wu, Y. and Li, Y. (2017) Impact of government intervention in the housing market: evidence from the housing purchase restriction policy in China. Applied Economics, 50 (6). pp. 691705. ISSN 0003-6846 doi:

https://doi.org/10.1080/00036846.2017.1340569 Available at https://centaur.reading.ac.uk/86647/

It is advisable to refer to the publisher's version if you intend to cite from the work. See Guidance on citing.

To link to this article DOI: http://dx.doi.org/10.1080/00036846.2017.1340569

Publisher: Taylor \& Francis

All outputs in CentAUR are protected by Intellectual Property Rights law, including copyright law. Copyright and IPR is retained by the creators or other copyright holders. Terms and conditions for use of this material are defined in the End User Agreement. 


\section{CentAUR}

Central Archive at the University of Reading

Reading's research outputs online 
Impact of Government Intervention in the Housing Market: Evidence from the Housing Purchase Restriction Policy in China

Yi Wu ${ }^{1}$ Yunong $\mathrm{Li}^{2}$

JEL Classification: C33;E61; 018;R30;R50

Abstract: In 2010, a housing purchase restriction policy was announced by China's central government and implemented gradually by several prefecture governments. In this paper, we empirically investigate this policy's effect on the housing market. Using a difference-in-difference (DID) framework, we show that the housing purchase restriction policy reduces housing prices and transaction amounts but does not influence the housing investment or construction markets. Moreover, upstream industry suffers more than downstream industry. The results are robust to a battery of robustness checks. Heterogeneity exists across cities. We find that first- and second-tier cities as well as highly urbanized cities experience great declines in housing prices after the policy’s implementation, especially cites that had high housing prices in 2010 and cities with high real estate investment as a proportion of fixed asset investment. However, the housing policy is less effective in curbing speculative demand.

Key word: Housing Purchase Restriction Policy; Difference-in-Difference; Housing Market; China

\section{Introduction}

Real estate is a pillar industry in China; it represented 12\% of Gross Domestic Product in GDP during the period from 2005 to 2013 with the total construction and real estate industries being approximately $\$ 1166$ billion U.S. (7229 billion RMB). Although it experienced a slight decline as the result of financial crisis, residential property investment accounts for approximately $19 \%$ of total fixed asset investment after 2011. ${ }^{3}$ Total residential loans issued by the four state-owned commercial banks grew to approximately U.S. $\$ 747.97$ billion (4600 billion RMB) by the end of 2013 up from approximately $\$ 43$ billion U.S. (355.6 billion RMB) in early 2000, with residential real estate mortgage loans estimated at U.S. \$1463.41 billion (9000 billion RMB) up from \$15.2 billion U.S. (126 billion

\footnotetext{
1 Corresponding author. Business School. Jinan University, Guangzhou, Guangdong,510632. China.; International School of Business \& Finance. Sun Yat-Sen University, Zhuhai, Guangdong, 519082. Email address: angeliawuyi@gmail.com

2 School of International Business. Southwestern University of Finance and Economics, Sichuan,China, 119077.

Email address:liyn@swufe.edu.cn

3 Data source: Chinese Statistical Yearbook (2000-2013)
} 
$\mathrm{RMB})$ in 1999.

Since the financial crisis, the growth rate of housing prices has averaged approximately $10 \%$ per annum (Deng, et al., 2015), and the trading volume has remained high during the period from 2009 to 2010 (Zhang, et al., 2015) despite cooling in the housing markets of other developed countries. A few cities in China experienced a dramatic surge in housing prices. For example, real estate prices in Shanghai increased by over 150\% between 2003 and 2010. ${ }^{4} \mathrm{Wu}$, Deng and Liu (2014) find a very high housing price appreciation rate in 35 cities bearing high risk. Meanwhile, according to the China Household Finance Survey, the average national vacancy rate climbed to 22.4\%, implying the existence of speculation in the Chinese housing market. Booming housing prices and a rising vacancy rate caused concern that a housing bubble might exist in China, and a high price-to-income ratio indicates the underlying risk of social welfare loss as housing becomes increasingly unaffordable in some places, especially in eastern region markets, such as Beijing and Shanghai. However, even affordable units made available through inclusionary housing policies may increase housing prices (Hughen and Read, 2014). Given looming social welfare losses, it became even more urgent for the Chinese government to implement restrictive measures on the purchase of real estate to effectively cool down the real estate market. The central government issued a series of intervention policies, such as a minimum down payment ratio and higher mortgage rates for a second home in early 2005, but the housing purchase restriction policy is the most stringent. This policy was announced by the central government in April 2010, and it was then implemented by some but not all cities. This nature of implementation defines the treatment group as the cities which adopt housing purchase restriction policy, and the other cities become the control group. As the treatment and control groups are based on an exogenously defined eligibility rule, we have a window of opportunity to conduct difference-in-difference (DID) estimation to credibly identify the treatment effects of the housing purchase restriction policy on city residential housing markets. (See table for details of housing purchase policy)

There have long been controversies about the role of government intervention in housing markets, especially housing policies (Allen and Carletti, 2013; Baldi, 2014; Cao et al., 2014; Crowe et al., 2013; Daniel and Hunt, 2014; Hui and Wang, 2014; Medrano and Spinelli, 2014; Wang et al., 2015; Wong et al., 2011). Theoretical models focus on government interventions in housing markets and their welfare implications (Gervais, 2002; Chambers et al., 2009; Cho and Francis, 2011; Sommer and Sullivan,

\footnotetext{
${ }^{4}$ Data source: Chinese City Statistical Yearbook (2003-2011)
} 
2013) by comparing steady states across policy regimes. In the short run, lending restrictions may disrupt untargeted housing markets, while having little influence on housing prices in the targeted market. However, when considering the transition between steady states, the effects of government interventions in the housing market may be large (Kirker, Stroebel and Floetotto, 2014). Further, in empirical settings, policies on the demand side, such as tax credits supporting house prices, take effect and increase trading volume over the short-run, while policies on the supply side, such as lending restrictions, have little influence on housing prices in the targeted market (Park. S, Bahng and Park, Y, 2010). In China, most research focuses on the introduction and documentation of policies (Wang and Murie, 1999, Deng et al., 2011), understanding housing affordability (Cai and Lu, 2015; Yuan and Hamori, 2014), analyzing the unequal outcomes of housing reform (Logan et al., 2010), or studying how the market forces of supply and demand interact to create shortages, bubbles, and other market conditions (Hou, 2010; Hui \& Shen, 2006).

Unlike previous papers, this study provides new evidence on the effects of government intervention on housing prices, the housing transaction market, housing investment and the construction market and related upstream and downstream industries supported by a rare quasi-natural experiment—a 2010 housing purchase restriction policy announced by the Chinese central government and subsequently adopted by some cities.

Although some Chinese scholars have explored this policy’s effects on the Beijing housing market from the perspective of resale and the rental market (Sun. et al., 2013) and the change in the correlation between price and volume (Zhang, et al., 2015), we consider its effect on the demand for and supply of housing and related upstream and downstream industries by employing data from 97 cities from January 2010 to December 2014. Our identification is essentially a difference-in-difference (DID) estimation: we compare housing prices, housing transaction volumes, housing investment and housing construction activities in restricted and unrestricted cities. First, we find that the housing purchase restriction policy has a negative and significant effect on housing prices. The results are the same using either the Newly Built Residential Housing Price Index or the Second-hand Residential Housing Price Index for 70 cities. This policy significantly influences the demand side, which is the housing transaction market (transaction amounts, transaction prices, transaction floors and sales amounts), but not the supply side, that is, the housing construction market (investment, floor under construction, floor started). Additionally, upstream industry suffers more than downstream industry. We also conduct a 
battery of robustness checks, considering pre-treatment and policy lag effects as well as variation in the policy implementation date. Our baseline result is robust to these checks. We further consider heterogeneity among cities. Specifically, we study whether the policy's effects are sensitive to a city's tier, residential population, geographical location, level of urbanization, real estate investment or local governmental land reliance. We find that the development of the city's real estate market rather than its size and location matters more for the effect of the housing policy. However, this policy is found to be less effective in the small-size and coastal city housing markets. We interpret these findings as evidence that the housing purchase restriction policy is not efficient in curbing speculative behavior.

We contribute to the government intervention literature in the following areas. First, taking advantage of a quasi-natural experiment in the housing market, we identify the impact of a housing purchase restriction policy, which is the most rigid type of housing policy, on housing prices, demand, and supply as well as on related upstream and downstream industries by employing a difference-in-difference strategy. This allows us to identify the effect of the policy without being affected by city fixed effects or time fixed effects. Second, instead of deriving theoretical results, we use real data to check whether housing policy effectively influenced the housing market according to the government's design. Third, we explore the most rigid government intervention policy in China and examine the housing market in detail, including the transaction market and the construction and related industries; this offers implications for other countries about the impact of government intervention in the real estate market. Fourth, the findings that the housing prices of first- and second-tier cities, cities with a high urbanization rate, or cities with high levels of real estate investment respond more significantly to the housing purchase restriction policy suggest that our results have broader implications for policymaking in other heated housing markets.

This paper proceeds as follows. In the next section, we briefly describe the details of the housing purchase restriction policy. Section 3 describes the empirical strategy and data sources. Section 4 provides the results in terms of the housing price, transaction market, housing investment and construction market and the effects on both upstream and downstream industries. Section 5 presents the robustness checks. Section 6 assesses the policy's effect on heterogeneous real estate markets. Section 7 offers a discussion and concludes.

\section{Background: The Housing Purchase Restriction Policy}


The government in China frequently intervenes in the real estate market (Ahuja et al., 2010) to maintain welfare equality and social stability. The Chinese government implemented a series of restrictive measures beyond traditional monetary and fiscal policies to prevent a housing price boom. Such measures include increasing the down payment ratio, prohibiting a mortgage on the purchase of a second house, and imposing taxes on housing transactions. The housing purchase restriction policy announced in 2010 was directly adopted at the city level and aimed at house buyers. It is the most restrictive policy used to suppress demand and limit speculation in the housing market.

The Chinese central government implemented the housing purchase restriction policy with the announcement of the "New National Ten Articles" in April 2010 as well as the "National Five Articles" in September 2010. The policy was adopted by a number of cities based on four criteria to guide the implementation of purchase restrictions devised by the Ministry of Housing and Urban-Rural Development. One criterion targeted cities in which residential prices climbed the fastest in 2010. Another two criteria addressed cities near provincial capitals as well as small cities that have had a low degree of compliance with past regulations and the real estate policies of their city governments. The final criterion applied to Tier 2 and Tier 3 cities mostly in coastal regions in which housing prices rose significantly in 2010. Provincial capitals and municipalities reporting directly to the central government should publish annual price control targets to keep new home costs "basically stable" as in the statement. Twenty local governments, such as Beijing, Shanghai and Guangzhou, issued specific execution plans in 2010 to curb their overheating real estate markets by imposing restrictions on purchasing power. Another 26 cities in total were to implement the housing purchase restriction policy in $2011 .^{5}$

According to the "New National Eight Articles" issued in April 2010, the general rule would be that only those with city hukou (household registration) or those who could prove that they had worked in the city for a certain number of consecutive years would be eligible to purchase property. Local city governments generally follow these rules to formulate their own regulations for home purchases. Effective proof requires either tax receipts or social security records for at least one year in most cities but at least five years in Beijing. However, there are no specific provisions on effective proof for citizens without hukou in twelve cities (Xiamen, Taiyuan, Haikou, Sanya, Jinan, Hefei, Zhoushan, Changsha, Lanzhou, Wulumuqi, Yinchuan, Huhehaote). Normally, citizens who have hukou can own a

\footnotetext{
5 The specific implementation dates for cities can be seen in Appendix Table 8.
} 
maximum of two houses in their names, while those relying on effective proof in the city can buy only one house. This restriction is particularly severe in Beijing in that citizens with hukou can only buy a second house two years after they bought a first house. This is generally to restrict purchases of newly built homes, although some cities (Shanghai, Xi'an, Qingdao, Taiyuan, Nanjing, Hangzhou, Wenzhou, Zhoushan, Quzhou, Haerbin, Dalian, Wuhan, Nanning, Nanchang, Huhehaote, Chengdu, Kunming) also impose restrictions on purchasing a second-hand house. However, 15 municipal authorities (i.e., Fuzhou, Taiyuan, Zhengzhou, Kunming, Zhuhai, Tianjin, Jinan, Shijiazhuang, Taiyuan, Xuzhou, Ha'erbin, Shenyang, Guiyang, Chengdu, Kunming, Changsha, Yinchuan) proposed an alternative policy, restricting house purchases only in the administrative regions of these cities, where housing prices and crowding are highest, rather than in the entire city.

According to statistical data from the National Bureau of Statistics of China, the Newly Built Residential Housing Price Index for 70 cities fell 6.5\% by in 2011 and contracted further in the beginning of 2012. The trading volume of newly built residential housing decreased by 64 percent and that of second-hand housing decreased by 65 percent in Beijing. These changes demonstrate the effects of the housing purchase restriction policy.

In summary, the housing purchase restriction policy had effects on the real estate market. We conduct a DID analysis focusing on the period from January 2010 to December 2014, which we will discuss in detail in the following sections.

\section{Empirical Strategy}

\section{Specification}

The housing purchase restriction policy (Xiangou Ling) was initiated by China's central government in April 2010. A total of 46 cities in our sample implemented this policy. Table 8 lists the policy implementation status of all house restriction policies for 97 cities in our benchmark sample, and Figure 2 illustrates the location of the cities that implemented restrictions. Beijing was the first city to enforce housing purchase restrictions in May 2010, followed by Shenzhen, Shanghai, Xiamen, Ningbo, Fuzhou, Hangzhou, Nanjing, Tianjin, Haikou, Guangzhou, Sanya and Wenzhou in October. The other 33 cities implemented the housing purchase restriction in succession. This quasi-natural experiment provides an opportunity to estimate the effectiveness of the purchase restriction policy in cooling down housing prices and its effects on the housing transaction, investment and construction markets in China. 
The 2010 housing restriction policy created variation among cities along two dimensions: first, dates before and after policy implementation; second, restricted and non-restricted cities. These variations allow us to conduct the empirical analysis using a DID framework. We compare the changes in housing prices of the restricted cities (treatment group) before and after the date of policy implementation with that of cities that did not implement the policy (control group). We first examine the average housing price among cities in both the treatment group and the control group. As shown in Figure 1, we find that the Newly Built Residential Housing Price Index of the cities in the treatment and control groups follow the same trend prior to the housing purchase restriction policy before 2010 . We can see from Fig. 1 that the housing prices of the two groups diverge as those in the treatment group experience less growth in housing prices, presumably due to the housing purchase restriction policy, starting from approximately 2011. This gives us a first impression that the housing purchase restriction may effectively reduce housing prices in the treatment group cities, which is the first main result of our paper.

We define a benchmark empirical equation using the logarithm of the average residential real estate price, $\ln (\text { Price })_{i t}$, as the dependent variable. We include an interaction between the treatment and policy variables to estimate the policy's effect on housing prices. The model specification is as follows:

$$
\ln (\text { Price })_{i t}=\alpha_{i}+\beta\left(\text { Treatment } \cdot \text { Post }_{i t}\right)+\tau_{t}+\text { trend }_{i t}+\varepsilon_{i t},
$$

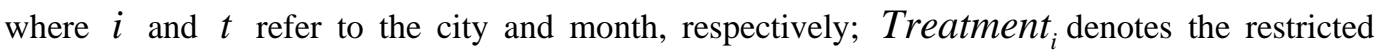
cities, taking a value of 1 if the city was restricted and 0 otherwise; Post ${ }_{i t}$ denotes the post-policy period, taking a value of 1 after the date of implementation for cities and 0 otherwise; $\alpha_{i}$ is the city fixed effect, controlling for all time-invariant differences across cities; $\tau_{t}$ is the month fixed effect, controlling for all month shocks that are common to cities; trend $_{i t}$ is the city-specific linear time trend and we also include the quadratic time trend for robustness check; and $\varepsilon_{i t}$ is the error term. $\beta$, the coefficient on the interaction term, is the main parameter of interest and measures the average treatment effect of the housing purchase restriction policy on housing prices after controlling for other confounding factors. 
To study the effects on housing transactions, housing investment, housing construction, and related industries, we replace $\ln (\text { Price })_{i t}$ with variables such as housing transaction volume, housing sales revenue, among others.

\section{Identification Checks}

The first concern is expectations prior to implementation of the housing purchase policy, that is, whether homebuyers adjusted their behavior before the policy was implemented in their cities. This will complicate the estimation of the housing purchase restriction effect. We conduct a placebo test by including an additional control in the baseline model, treatment ${ }_{i} \times$ Month $_{i t}$, where Month $_{i t}$ equals 1 if the policy was implemented within three months and 0 otherwise, to examine whether housing prices began declining due to anticipation of the housing purchase restriction policy.

Moreover, considering the timing of the policy, we assume that the policy takes effect in the month of the announcement date in our baseline estimation. In a robustness check, we adjust the month in which the policy takes effect for dates that fall in the last third of the month, and we consider the following month to represent when the restriction begins.

A third concern may be about the comparability of our treatment and control groups. Because some cities in our treatment group implemented the provincial restriction policy in 2011, while others implemented it earlier in $2010^{6}$, we can perform another test using cities that implemented this policy late in 2011 as the control group and cities that implemented this policy early in 2010 as the treatment group. The new control and treatment groups are more comparable, as cities from both groups adopted the policy and only differed in the timing of implementation.

\section{Data Source and Variables}

We collect data from the WIND database, the National Bureau of Statistics of China, the China City Statistical Yearbook and the SouFuncom Website ${ }^{7}$. We focus on data for the residential market, as the primary purpose of the housing purchase restriction policy from the "New National Ten Articles" is to dampen the residential housing price surge. The average residential housing price data cover 97

\footnotetext{
${ }^{6}$ See Appendix Figure 2 and Table 8.

7 http://www.fang.com/
} 
cities $^{8}$ from January 2010 to December 2014, while the Newly Built Residential Housing Price Index, Second-Hand Residential Housing Price index and Small-size Housing Price Index ${ }^{9}$ for 70 cities offer data from January 2006 to February 2015. To achieve consistency in the data, we adjust them into indices for the period January 2010 to December 2014 to avoid the structural break from the financial crisis in 2008. We also use several variables in the housing transaction market, specifically the transaction amount, transaction price, transaction floor and sales amount. Data are available for 19 cities for the transaction floor, 10 cities for calculating the transaction amount, 16 cities for the transaction price, and 29 cities for the sales amount. Meanwhile, for the housing investment and construction markets, we have a sample of 29 cities for real estate investment and 23 cities for floor under construction and newly started. Considering the upstream and downstream industries, we use concrete prices as the proxies. We have a price for 32.5 concrete for 110 cities, a type that is mostly used in the housing renovations industry and for 42.5 concrete for 114 cities, a type that is an important input for housing construction. We use concrete prices as the proxies because concrete is usually locally supplied due to its high transportation cost, and thus, its price primarily reflects information about the local market. We also include the disposable income, GDP, CPI and fixed asset investment for 70 cities as control variables in the empirical test. The variables and their descriptions are listed in Appendix Tables 9 and 10.

\section{Empirical Results}

\section{Main Results}

We first use the full sample of 97 cities. The results of our baseline DID specification for equation (1) are reported in Table 1. We first start with a simple DID specification, without controlling for fixed effects by cities or dates, in Column 1. After we control the city fixed effects and month fixed effects, our regressor of interest, treatment $_{i} \times$ Post $_{i t}$, is statistically significant and negative, suggesting an Average Housing Price decrease in the cities with housing purchase restrictions. Column 3 includes controls for the linear time-trend of housing prices in these cities; this filters out the city-specific trend,

\footnotetext{
8 The 97 cities are randomized across China, which include the 46 constrained cities in the treatment group and other 51 cities in the control group. The nearly balance number of cities in treatment group and control group make our empirical results are more convincing. The average residential housing price data cover 97 cities has been deflated by inflation.

${ }^{9}$ A small-size house refers to a house with a living area of not more than 90 square meters, according to the definition of Chinese State Statistical Bureau.
} 
which may confound the effect of the house purchase restrictions. The estimate on the interaction between the post-policy and treatment indicators is still negative and significant at a $1 \%$ level, which confirms the graphical results that the housing purchase restriction policy effectively reduced housing prices. Further, we include the quadratic time trend in column 4 for robustness check. It shows the consistent results. ${ }^{10}$

To confirm the results in Table 1, we replace the Real Average Residential Housing Price with the Newly Built Residential Housing Price Index in Column 1 of Table 2. We still find a significant and negative estimated effect for the policy. In Column 2 of Table 2, the restricted cities experienced a 1.51 percentage point decrease in the Second-Hand Residential Housing Price Index after policy implementation, significant at a $1 \%$ level. This suggests that the policy also affects prices in the second-hand residential market and that the policy particularly dampens the demand for houses. The bone of contention regarding high housing prices is that those in the middle and lower classes cannot afford to buy homes, while the wealthy, regarded as speculators, benefit from the housing price surge. We next check the policy impact on small-size residential houses, which particularly reflect the demand for houses for ordinary residential use. The estimated coefficients in column 3 show a significant drop in the price index for small-size residential houses, but the effect is much smaller than the baseline result. We consider this smaller effect to be important evidence that the housing purchase restrictions did not dampen speculative demand much more than the demand for ordinary residential housing.

We next examine the effect of the policy on the housing transaction market. The first three columns in Table 3 present the estimation results for the transaction amount, transaction price and transaction floor in the new residential housing market. The willingness of citizens to buy a new house has largely decreased with the implementation of the policy, as is clear from the negative coefficient of the interaction term. The housing purchase restriction policy directly led to a plunge in the transaction price and in the floor space sold of -6.53 percentage points and -11.41 percentage points, respectively, which are significant at the $1 \%$ and $10 \%$ levels. These changes contribute to decreasing sales volume. These results signal that demand in the housing market decreased after the housing purchase restriction policy.

We further consider the reactions of the housing investment and construction markets to the ${ }^{10}$ We also tried the cubic time trend and high order time trend, the main results are also the same as the linear time
trend, so we only report results including the linear time trend in the following empirical findings. 
housing purchase restriction policy. While the policy directly targets purchases of residential housing, the supply side may adjust as well. Given the significant number of non-occupied residential units in some cities, policymakers evidently also worry about surpluses of residential housing in some cities. They may welcome the housing purchase restriction policy if it also cools down the supply of residential housing. However, no significant impact on real estate investment is found, although its coefficient is negative. The results shown in Columns 2 and 3 of Table 4 imply that there is little evidence of a policy effect on the real estate construction market. Moreover, these findings are reinforced when we examine both upstream and downstream industries. In fact, the price of 32.5 concrete, which is used for home renovations, significantly increased after the policy was implemented. However, the price of 42.5 concrete, which is used for house construction, decreased slightly. There is thus no evidence found that this policy slows either the supply of residential homes or its upstream and downstream industries.

\section{Robustness}

In this subsection, we report results of a battery of robustness checks on the identifying assumptions of our aforementioned DID estimation.

\section{Placebo Test: Pre-policy Period}

In a placebo test, we address the effect of the policy on housing prices in the pre-policy period when there are other policies that will change the trend of housing prices. We include the interaction terms between policy implementation status and a dummy variable that takes the value 1 for the 1,2 , or 3 months before the policy implementation and 0 otherwise. We find that the coefficients are not significant; if we found otherwise, that could indicate the existence of underlying confounding factors. As shown in Column 1 of Table 5, we find that housing prices did not decrease during the pre-policy period.

\section{Policy Lag Effect}

Our previous results are based on the premise that the local policies took effect in the same month as the announcements, even though some local governments made their announcements in the second half of the month. We consider the time lag of the policy effect. We take the exact date of the policy 
and separate these cities into different groups. If the announcement date from the local government is before the middle of the month, the city is treated in that month. If the announcement date is after the middle of the month, we assume that the policy will take effect in the next month. We still find a robust result for treatment $_{i} \times$ Post $_{i t}$, which is significantly negative.

\section{Variation in the Policy Implementation Date}

We consider different dates on which the housing policy is implemented across restricted cities, allowing us to implement another important robustness check. We separate the cities in the benchmark treatment group into two new treatment and control groups. The cities in the new treatment group are those in which the housing policy took effect before 2011, and the others are the cities in which the policy took effect after 2011 (control group). One important concern for the benchmark treatment and control groups is their comparability, as the restricted and non-restricted cities could be very different. However, the cities in our new treatment and control groups all adopted this policy and differed only in the date of implementation. The cities in these two groups are more comparable than the benchmark treatment and control groups. We still find significant a negative coefficient for the interaction term.

\section{Heterogeneous Effects}

Our aforementioned analyses estimate the average effect of the housing policy on residential housing prices across cities. In this subsection, we investigate the heterogeneous effects of the housing policy by city geographic division, city size and city development status, as discussed in Section 2, to further elucidate how the housing purchase restriction policy affects housing prices. The policy to curb housing price increases is primarily targeted at first- and second-tier cities because most of these are capital cities. Further, the local governments in first- and second-tier cities were first to implement the policy after the central government announcement. Following these details, we add an interaction between our regressor of interest treatment $_{i} \times$ Post $_{i t}$ and the indicator variable Tier $_{i}$, which is 1 if the city is either a first- or second-tier city and 0 otherwise. Estimation results including the new interaction term are reported in Column 1 of Table 6. There is a negative and significant effect of the housing purchase policy on housing prices. This result suggests that much of the housing policy's effect on first- and second- tier cities is in line with its original purpose. 
Next, we check whether the policy’s effect depends on the city's location. Because house prices in coastal cities are more inflated by speculation than those in inland cities (Zhang, et al., 2015), the housing purchase restriction policy should have a greater effect on coastal cities, as it may curb investment motivated housing purchases. We create an interaction term, treatment $_{i} \times$ Post $_{i t}$, and the geographic indicator Coastal $_{i}$, which is equal to 1 if the city is on the coastal line and 0 otherwise. The regression result is reported in Column 2 of Table 6. The effect on cities in coastal regions is not larger than that in inland regions, which may imply that the policy is not effective in curbing speculative demand. Moreover, although the official documents clearly prescribe differential treatment of citizens with hukou, it is difficult to measure the real demand due to migration. Instead, we use the residential population to evaluate the real demand for housing in the city. We create an indicator variable for the residential population. If Population $_{i}$ variable for cities is equal to 1, the residential population of cities is above the median of all cities from 2009 to 2014. Then, the interaction term

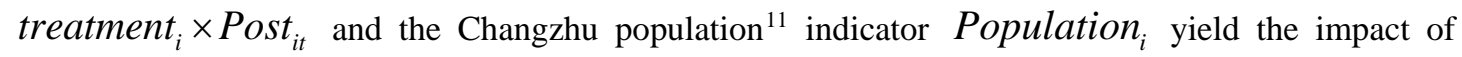
the policy on high changzhu population areas. Column 3 of Table 6 indicates that housing prices in cities with larger changzhu populations did not decline significantly more than prices in cities with smaller changezhu populations.

On the other hand, the development of the real estate market matters. The housing purchase restriction policy was implemented mostly in cities that had high housing prices in 2010, as discussed in section 2. ${ }^{12}$ We create an indicator variable for cities according to the rank of each city in 2010. Rank $_{i}$ equals 1 if the housing prices of these cities rank in the top 50 in 2010, and 0 otherwise. Then, we add a new interaction between our regressor of interest treatment $_{i} \times$ Post $_{i t}$ and the indicator variable $\operatorname{Rank}_{i}$. The regression results using the new interaction term are reported in Column 1 of

\footnotetext{
11 There are two kinds of population data in China, i.e. hukou population and changzhu population. The hukou population refers to people who registered with the police under the household registration system but does not include residents living in the city without local hukou, whereas the changzhu population refers to the resident population that has stayed in the same area for more than 6 months and reflects the migration pattern. For a coastal city where the manufacturing industry concentrates and hence becomes the residence of numerous migrants, the hukou population might underestimate the total number of residents. For an inland city that is the home of migrants, the hukou population might overestimate its total residents. To avoid this bias, we collect the data of changzhu population from the yearbooks of each city or province because changzhu population instead of hukou population represents the real potential demand for urban residential housing.

12 We rank the cities according to their residential housing prices in 2010 and list the cities ranking in the top 100 in the Appendix Table 11.
} 
Table 7. The coefficient is negative and significant at a $1 \%$ level, implying that the effect of the housing purchase restriction policy on cities with high housing prices is larger than in cities with low housing prices.

The level of real estate investment in fixed asset investment is a key factor for evaluating the development of a regional real estate market as well as of the local economy. To consider variation in development among city real estate markets, we calculate the average percentage of real estate investment of fixed asset investment for each city during the year from 2010 to 2014 . Next, we create an indicator variable Investment $_{i}$ to evaluate the importance of the real estate industry in the local economy for each city. If the Investment ${ }_{i}$ of a city equals 1 , it means that its' real estate investment is above the median value of the full sample and 0 otherwise. Then we obtain the new interaction between our regressor of interest treatment $_{i} \times$ Post $_{i t}$ and the indicator variable Investment ${ }_{i}$. We can conclude from the regression results in Column 2 of Table 7 that the policy effect in cities with active real estate investment is greater than that in cities with a lower ratio of real estate investment to fixed asset investment.

The urbanization process is the main factor increasing housing prices in Chinese cities. We construct an urbanization index for cities via principal component analysis ${ }^{13}$ to evaluate the level of urbanization. Then, we define the indicator variable for urbanization with an above the median value of the urbanization index. If the Urbanization Un $_{i}$ of cities is equal to 1 , the city has a high level of urbanization. Column 3 of Table 7 shows that the three-way interaction term is statistically significant, implying that cities with higher levels of urbanization are more affected by the policy than less urbanized cities.

Considering land sales appreciation to be a major non-tax fiscal income source for local governments, as discussed in section 2, we use local fiscal conditions to proxy for local government reliance on land revenue (Deng, et al., 2012). The local fiscal condition is calculated as the ratio between local budgetary fiscal expenditures and budgetary income in city $i$, and then, the mean value of the previous years is taken. The variable Deficit $_{i}$ equals one if the local fiscal condition is above

\footnotetext{
${ }^{13}$ The main factor involves the percentages of non-agricultural population and floating population of the total population, GDP per capita and percentage of GDP from tertiary industry of total GDP.
} 
the median value of the full sample and 0 otherwise. Column 4 of Table 7 indicates that cities with a high reliance on land revenue do not experience greater declines in housing prices.

\section{Conclusions and Discussions}

Residential property accounts for the largest part of Chinese household investment-approximately $60 \%$ to $80 \%$. Skyrocketing housing prices sow discontent among Chinese citizens. To efficiently control soaring housing prices, the Chinese government embarked upon a rigorous housing purchase restriction policy in October 2010, and this policy was subsequently implemented by 46 local governments. This paper evaluates the impact of the housing purchase restriction policy on housing prices, the housing transaction market, housing investment, the construction market, and related upstream and downstream industries in a DID framework. We first use a sample of 97 cities from January 2010 to December 2014 to obtain our baseline estimation of the policy's effect on housing prices and then use the Newly Built Housing Price, Second-hand Housing Price and Small-size Housing Price indices for a sample of 70 cities to check the robustness of our results. A significant decrease in housing prices is found due to the housing purchase restriction policy. The number of transactions, transacted floor and sales, which reflect the level of activity in the housing market, decline approximately 4 percent to 12 percent after policy implementation. However, housing investment and construction are not influenced, which indicates that the potential housing price increasing in the future. Moreover, the price of 32.5 concrete, used as a proxy for downstream industries in the housing market, actually increases, while the price of 42.5 concrete as a proxy for upstream industries in the housing market decreases, although not significantly. Our result for housing prices passes a battery of robustness checks with respect to pre-treatment effects, policy lag issues, and variation in the policy implementation dates. Heterogeneity exists across cities. We find that first- and second-tier cities and highly urbanized cities experience greater declines in housing prices. The policy is also more effective in cities that had high housing prices in 2010, which is in line with the purpose of the policy. Cities that have high real estate investment as a portion of fixed asset investment are also more responsive to the housing purchase restriction.

This paper provides a comprehensive empirical analysis of the housing purchase restriction policy in China, which provides new evidence for the effects of government intervention in the housing market. Aside from housing prices, this paper broadens our understanding of the effects on the housing 
transaction, housing investment and construction markets as well as on related upstream and downstream industries.

Our findings that the housing purchase restriction policy significantly decreases both housing prices and housing transactions in China may have broader implications for policymaking in other countries, especially in developing countries that experience similarly skyrocketing housing prices. Demand for houses was more affected than was the supply of houses; however, there is little evidence that this policy is effective in controlling speculative demand. Moreover, the proportion of land sales through public auctions has positive effects on local GDP growth (Li, 2014). We should consider whether decreases in the land sale revenues after implementation of the housing purchase restriction policy result in the repeal of the policy. We will explore the details of the housing policy effects on local government behavior, which is beyond the scope of this study, in future work.

Obviously, the original purpose of the housing purchase restriction policy is to control excessive speculation in the housing market, which is pushing up housing prices. It is not sufficient to separate investors based on hukou registration alone; however, it is difficult to track investor behavior. We suggest the establishment of an online individual housing transaction record system, which may be more effective in monitoring and potentially limiting speculative behavior. We could then track each individual's housing transactions and control short-term trading. A Web-based system, where the government put quantity restrictions on housing trading in a transparent system, will more effectively target speculative investors because houses trading at very high multiples of rent will lead to a negative shock in terms of policy intervention or further slowing of economic growth (Deng, et al., 2015). It is more efficient to improve housing market by increasing urbanization rate for cities at this stage rather than curbing housing price directly. Urban policy makers in China do not the need for deregulation but the need for policy coordination.

\section{References}

Allen, F.,\& Carletti, E. (2013). Systemic risk from real estate and macro-prudential regulation. International Journal of Banking, Accounting and Finance, 5(1), 28-48. doi:10.1504/ijbaaf.2013.058091

Ahuja, A., \& Myrvoda, A. (2012). The Spillover Effects of a Downturn in China's Real Estate Investment. SSRN 2183026 doi:10.5089/9781475549003.001 
Baldi, G.(2014). The economic effects of a central bank reacting to house price inflation. Journal of Housing Economics, 26, 119-125. doi:10.1016/j.jhe.2014.09.004

Cai, H., Henderson, J. V., \& Zhang, Q. (2013). China's land market auctions: evidence of corruption? The Rand journal of economics, 44(3), 488-521. doi: 10.1111/1756-2171.12028

Cai, H., Wang, Z., \& Zhang, Q. (2014). To build above the limit? Implementation of land use regulations in urban China. Working paper

Cai, W., \& Lu, X. (2015). Housing affordability: Beyond the income and price terms, using China as a case study. Habitat International, 47, 169-175 doi:10.1016/j.habitatint.2015.01.021

Cao, J. A., \& Keivani, R. (2014). The Limits and Potentials of the Housing Market Enabling Paradigm: An Evaluation of China's Housing Policies from 1998 to 2011. Housing Studies, 29(1), 44-68. doi:10.1080/02673037.2013.818619

Chambers, M., Garriga, C., \& Schlagenhauf, D. E. (2009). Housing policy and the progressivity of income taxation. Journal of Monetary Economics, 56(8), 1116-1134. doi:10.1016/j.jmoneco.2009.10.007

Cho, S. and J. Francis (2011). Tax treatment of owner occupied housing and wealth inequality. 33 (1), 42-60. doi:10.1016/j.jmacro.2010.09.002

Crowe, C., Dell’Ariccia, G., Igan, D., \& Rabanal, P. (2013). How to deal with real estate booms: lessons from country experiences. Journal of Financial Stability, 9(3), 300-319. doi:10.1016/j.jfs.2013.05.003

Daniel, M. M., \& Hunt, R. J. (2014). Changing housing policies and housing provision in Jos, Nigeria. Habitat International, 42, 203-213. doi:10.1016/j.habitatint.2013.11.004

Deng, L., Shen, Q., \& Wang, L. (2011). The emerging housing policy framework in China. Journal of Planning Literature, 26(2), 168-183. doi:10.1177/0885412210390220

Deng, Y., Gyourko, J., \& Wu, J. (2012). Land and house price measurement in China . NBER working paper. (No. w18403) doi:10.3386/w18403

Deng, Y., Gyourko, J., \& Wu, J (2015). Evaluating the Risk of Chinese Housing Markets: What We Know and What We Need to Know. Working paper

Gervais, M. (2002). Housing taxation and capital accumulation. Journal of Monetary Economics 49 (7), 1461. doi:10.1016/s0304-3932(02)00172-1

Medrano, L., \& Spinelli, J. (2014). Urban policies and projects for social housing in central areas. The 
case of the Habitasampa competition (São Paulo, Brazil). Habitat International, 42, 39-47. doi:10.1016/j.habitatint.2013.10.004

Fang, H., Gu, Q., \& Zhou, L. A. (2014). The Gradients of Power: Evidence from the Chinese Housing Market. NBER working paper (No. w20317)

Kirker, M., Stroebel, J., \& Floetotto, M. (2014). Government Intervention in the Housing Market: Who Wins, Who Loses? Who Loses. SSRN 1582296 doi:10.2139/ssrn.1582296

Hughen, W. K., \& Read, D. C. (2014). Inclusionary housing policies, stigma effects and strategic production decisions. The Journal of Real Estate Finance and Economics, 48(4), 589-610. doi:10.1007/s11146-013-9402-7

Hui, E. C., \& Wang, Z. (2014). Price anomalies and effectiveness of macro control policies: Evidence from Chinese housing markets. Land Use Policy, 39, 96-109. doi:10.1016/j.landusepol.2014.04.003

Hui, E. C., \& Yue, S. (2006). Housing price bubbles in Hong Kong, Beijing and Shanghai: a comparative study. The Journal of Real Estate Finance and Economics, 33(4), 299-327. doi:10.1007/s11146-006-0335-2

Hou,Y. (2010). Housing price bubbles in Beijing and Shanghai? A multi-indicator analysis. International Journal of Housing Markets and Analysis,3(1), 17-37. doi:10.1108/17538271011027050

Logan, J. R., Fang, Y., \& Zhang, Z. (2010). The winners in China's urban housing reform. Housing Studies, 25(1), 101-117. doi:10.1080/02673030903240660

Li, J. (2014). Land sale venue and economic growth path: Evidence from China's urban land market. Habitat International, 41, 307-313. doi:10.1016/j.habitatint.2013.10.001

Park, S. W., Bahng, D. W., \& Park, Y. W. (2010). Price run-up in housing markets, access to bank lending and house prices in Korea. The Journal of Real Estate Finance and Economics, 40(3), 332-367. doi:10.1007/s11146-008-9143-1

Sommer, K. and P. Sullivan (2013). Implications of U.S. tax policy for house prices, rents and homeownership. Working paper

Sun, W., Zheng, S., Geltner, D. M., \& Wang, R. (2013). The Housing Market Effects of Local Home Purchase Restrictions: Evidence from Beijing. Tsinghua University Working paper

Wang, X. R., Hui, E. C. M., Choguill, C., \& Jia, S. H. (2015). The new urbanization policy in China: Which way forward? Habitat International, 47, 279-284. doi:10.1016/j.habitatint.2015.02.001

Wong, T. C., Fong, T., Li, K. F., \& Choi, H. (2011). Loan-to-value ratio as a macroprudential tool-Hong 
Kong's experience and cross-country evidence.SSRN working paper. doi: 10.2139/ssrn.1768546

Wu, J., Deng, Y., \& Liu, H. (2014). House price index construction in the nascent housing market: the case of China. The Journal of Real Estate Finance and Economics, 48(3), 522-54 doi:10.1007/s11146-013-9416-1

Yuan, N., \& Hamori, S. (2014). Crowding-out effects of affordable and unaffordable housing in China, 1999-2010. Applied Economics, 46(35), 4318-4333 doi:10.1080/00036846.2014.957441

Zhang, L., Hui, E. C. M., \& Wen, H. (2015). Housing price-volume dynamics under the regulation policy: Difference between Chinese coastal and inland cities. Habitat International, 47, 29-40. doi:10.1016/j.habitatint.2015.01.003 


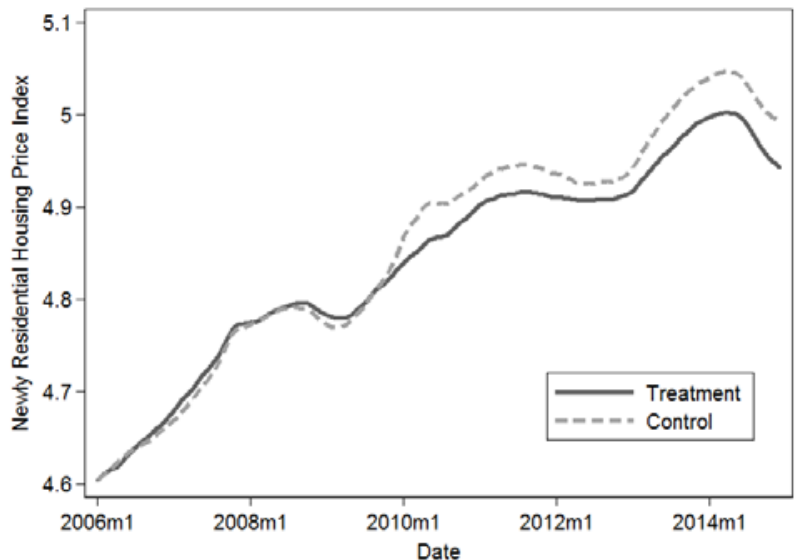

Fig.1 Trend in Newly Built Residential Housing Price Index from January 2006 to February 2015 
Table 1 Baseline Model

\begin{tabular}{|c|c|c|c|c|}
\hline Dependent Variable: & (1) & $(2)$ & (3) & (4) \\
\hline \multicolumn{5}{|c|}{ Average Residential Housing Price (in log form) } \\
\hline \multirow[t]{2}{*}{ treatment $_{i} \times$ Post $_{i t}$} & $0.4544 * * *$ & $-0.0157 * * *$ & $-0.0154 * * *$ & $-0.0074 * *$ \\
\hline & $(0.0113)$ & $(0.0062)$ & $(0.0039)$ & $(0.0031)$ \\
\hline City Linear Trend & & & $\mathrm{Y}$ & $\mathrm{Y}$ \\
\hline City Quadratic Trend & & & & $\mathrm{Y}$ \\
\hline City Fixed Effects & & $\mathrm{Y}$ & $\mathrm{Y}$ & $\mathrm{Y}$ \\
\hline Month Fixed Effects & & Y & $\mathrm{Y}$ & Y \\
\hline Observations & 5,586 & 5,586 & 5,586 & 5586 \\
\hline R-squared & 0.2907 & 0.9744 & 0.9922 & 0.9958 \\
\hline
\end{tabular}

Note: Bootstrap standard errors in parentheses. ${ }^{* * *} \mathrm{p}<0.01,{ }^{* *} \mathrm{p}<0.05,{ }^{*} \mathrm{p}<0.1$ 
Table 2 Checks on the Identifying Assumptions

\begin{tabular}{cccc}
\hline & $(1)$ & $(2)$ & $(3)$ \\
\hline Dependent Variables: & Newly Built & Second-hand & Small-size \\
& Residential & Residential & Residential \\
& Housing Price & Housing Price & Housing Price \\
& Index & Index & Index \\
\hline treatment ${ }_{i} \times$ Post $_{i t}$ & $-0.0119^{* * *}$ & $-0.0151^{* * *}$ & $-0.0037^{* *}$ \\
City Linear Trend & $(0.0015)$ & $(0.0018)$ & $(0.0018)$ \\
City Fixed Effects & $\mathrm{Y}$ & $\mathrm{Y}$ & $\mathrm{Y}$ \\
Month Fixed Effects & $\mathrm{Y}$ & $\mathrm{Y}$ & $\mathrm{Y}$ \\
Observations & $\mathrm{Y}$ & $\mathrm{Y}$ & $\mathrm{Y}$ \\
R-squared & 4340 & 4216 & 4204 \\
Note: Bootstrap standard errors in parentheses. ${ }^{* * *} \mathrm{p}<0.01, * * \mathrm{p}<0.05, * \mathrm{p}<0.1$
\end{tabular}


Table 3 Residential Housing Transaction Market

\begin{tabular}{lcccc}
\hline & $(1)$ & $(2)$ & $(3)$ & $(4)$ \\
\hline Dependent variables: & Amount & Price & Floor & Sales \\
& & & & Amount \\
\hline treatment $_{i} \times$ Post $_{i t}$ & -0.1206 & $-0.0653^{* * *}$ & $-0.1141^{*}$ & -0.0412 \\
City Linear Trend & $(0.0986)$ & $(0.0225)$ & $(0.0655)$ & $(0.0340)$. \\
City Fixed Effects & $\mathrm{Y}$ & $\mathrm{Y}$ & $\mathrm{Y}$ & $\mathrm{Y}$ \\
Month Fixed Effects & $\mathrm{Y}$ & $\mathrm{Y}$ & $\mathrm{Y}$ & $\mathrm{Y}$ \\
Observations & $\mathrm{Y}$ & $\mathrm{Y}$ & $\mathrm{Y}$ & $\mathrm{Y}$ \\
R-squared & 560 & 892 & 1088 & 1403 \\
\hline
\end{tabular}

Note: Bootstrap standard errors in parentheses. ${ }^{* * *} \mathrm{p}<0.01,{ }^{* *} \mathrm{p}<0.05,{ }^{*} \mathrm{p}<0.1$ 
Table 4 Residential Housing Construction Market

\begin{tabular}{lccccc}
\hline & $(1)$ & $(2)$ & $(3)$ & $(4)$ & $(5)$ \\
\hline Dependent Variables: & $\begin{array}{c}\text { Real Estate } \\
\text { Investment }\end{array}$ & $\begin{array}{c}\text { Floor Under } \\
\text { Construction }\end{array}$ & Floor Started & $\begin{array}{c}32.5 \text { Concrete } \\
\text { Price }\end{array}$ & $\begin{array}{c}\text { Concrete } \\
\text { Price }\end{array}$ \\
\hline treatment \\
\end{tabular}


Table 5 Robustness Checks

\begin{tabular}{|c|c|c|c|}
\hline & (1) & (2) & (3) \\
\hline \multirow{3}{*}{$\begin{array}{l}\text { Dependent variable: } \\
\text { Average Housing Price }\end{array}$} & Placebo Test & Policy Lag & Policy \\
\hline & & Effect & Implementation \\
\hline & & & Variation \\
\hline \multirow{2}{*}{ treatment $_{i} \times$ Post $_{i t}$} & $-0.0133 * * *$ & $-0.0157 * * *$ & $-0.0242 * *$ \\
\hline & $(0.0047)$ & $(0.0042)$ & $(0.0145)$ \\
\hline \multirow{2}{*}{ treatment $_{i} \times$ Month $_{i t}$} & 0.0033 & & \\
\hline & $(0.0083)$ & & \\
\hline \multirow{2}{*}{ treatment $_{i} \times 2$ Month $_{i t}$} & 0.0030 & & \\
\hline & $(0.0008)$ & & \\
\hline \multirow{2}{*}{ treatment $_{i} \times 3$ Month $_{i t}$} & 0.0056 & & \\
\hline & $(0.0084)$ & & \\
\hline City Linear Trend & $\mathrm{Y}$ & $\mathrm{Y}$ & $\mathrm{Y}$ \\
\hline City Fixed Effects & $\mathrm{Y}$ & $\mathrm{Y}$ & $\mathrm{Y}$ \\
\hline Month Fixed Effects & $\mathrm{Y}$ & $\mathrm{Y}$ & $\mathrm{Y}$ \\
\hline Observations & 5586 & 5586 & 2451 \\
\hline R-squared & 0.9922 & 0.9922 & 0.9933 \\
\hline
\end{tabular}

Note: Bootstrap standard errors in parentheses. ${ }^{* * *} \mathrm{p}<0.01,{ }^{* *} \mathrm{p}<0.05{ }^{*} \mathrm{p}<0.1$ 
Table 6 Heterogeneous Effects by City Location and City Size

\begin{tabular}{lccc}
\hline & $(1)$ & $(2)$ & $(3)$ \\
\hline Dependent variable: & First- and Second-tier & Coastal Cities & Residential \\
Average Housing Price & Cities & & Population \\
\hline treatment $_{i} \times$ Post $_{i t}$ & -0.0087 & $-0.0135^{* * *}$ & $-0.0226^{* * *}$ \\
treatment $_{i} \times$ Post $_{i t} \times$ Tier $_{i}$ & $(0.0054)$ & $(0.0037)$ & $(0.0038)$ \\
& $-0.0143^{* *}$ & & \\
treatment $_{i} \times$ Post $_{i t} \times$ Coastal $_{i}$ & $(0.0070)$ & -0.0038 & $(0.0063)$ \\
treatment $_{i} \times$ Post $_{i t} \times$ Population $_{i}$ & & & -0.0025 \\
City Linear Trend & & & $(0.0036)$ \\
City Fixed Effects & & $\mathrm{Y}$ & $\mathrm{Y}$ \\
Month Fixed Effects & $\mathrm{Y}$ & $\mathrm{Y}$ & $\mathrm{Y}$ \\
Observations & $\mathrm{Y}$ & $\mathrm{Y}$ & $\mathrm{Y}$ \\
R-squared & $\mathrm{Y}$ & 5586 & 4070 \\
\hline
\end{tabular}

Note: Bootstrap standard errors in parentheses. *** $\mathrm{p}<0.01,{ }^{* *} \mathrm{p}<0.05,{ }^{*} \mathrm{p}<0.1$ 
Table 7 Heterogeneous Effects by City Development

\begin{tabular}{|c|c|c|c|c|}
\hline & (1) & (2) & (3) & (4) \\
\hline Dependent Variable: & Housing Price & Real Estate & Urbanization & Local \\
\hline \multirow[t]{2}{*}{ Average Housing Price } & in 2010 & Investment & & Government \\
\hline & & & & Deficit \\
\hline \multirow{2}{*}{ treatment $_{i} \times$ Post $_{i t}$} & $0.0464 * * *$ & -0.0006 & -0.0004 & $-0.0153^{* * *}$ \\
\hline & $(0.0091)$ & $(0.0070)$ & $(0.0051)$ & $(0.0040)$ \\
\hline \multirow[t]{2}{*}{ treatment $_{i} \times$ Post $_{i t} \times$ Rank $_{i}$} & $-0.0833 * * *$ & & & \\
\hline & $(0.0087)$ & & & \\
\hline \multirow[t]{2}{*}{ treatment $_{i} \times$ Post $_{i t} \times$ Investment $_{i}$} & & $-0.0143^{* *}$ & & \\
\hline & & $(0.0067)$ & & \\
\hline \multirow[t]{2}{*}{ treatment $_{i} \times$ Post $_{i t} \times$ Urbanization $_{i}$} & & & $-0.0251^{* * *}$ & \\
\hline & & & $(0.0070)$ & \\
\hline \multirow[t]{2}{*}{ treatment $_{i} \times$ Post $_{i t} \times$ Deficit $_{i}$} & & & & 0.0039 \\
\hline & & & & $(0.0093)$ \\
\hline City Linear Trend & $\mathrm{Y}$ & $\mathrm{Y}$ & $\mathrm{Y}$ & $\mathrm{Y}$ \\
\hline City Fixed Effects & $\mathrm{Y}$ & $\mathrm{Y}$ & $\mathrm{Y}$ & $\mathrm{Y}$ \\
\hline Month Fixed Effects & $\mathrm{Y}$ & $\mathrm{Y}$ & $\mathrm{Y}$ & $\mathrm{Y}$ \\
\hline Observations & 5586 & 2860 & 5301 & 5301 \\
\hline R-squared & 0.9924 & 0.9917 & 0.9937 & 0.9936 \\
\hline
\end{tabular}

Note: Bootstrap standard errors in parentheses. ${ }^{* * *} \mathrm{p}<0.01,{ }^{* *} \mathrm{p}<0.05,{ }^{*} \mathrm{p}<0.1$ 


\section{Appendix:}

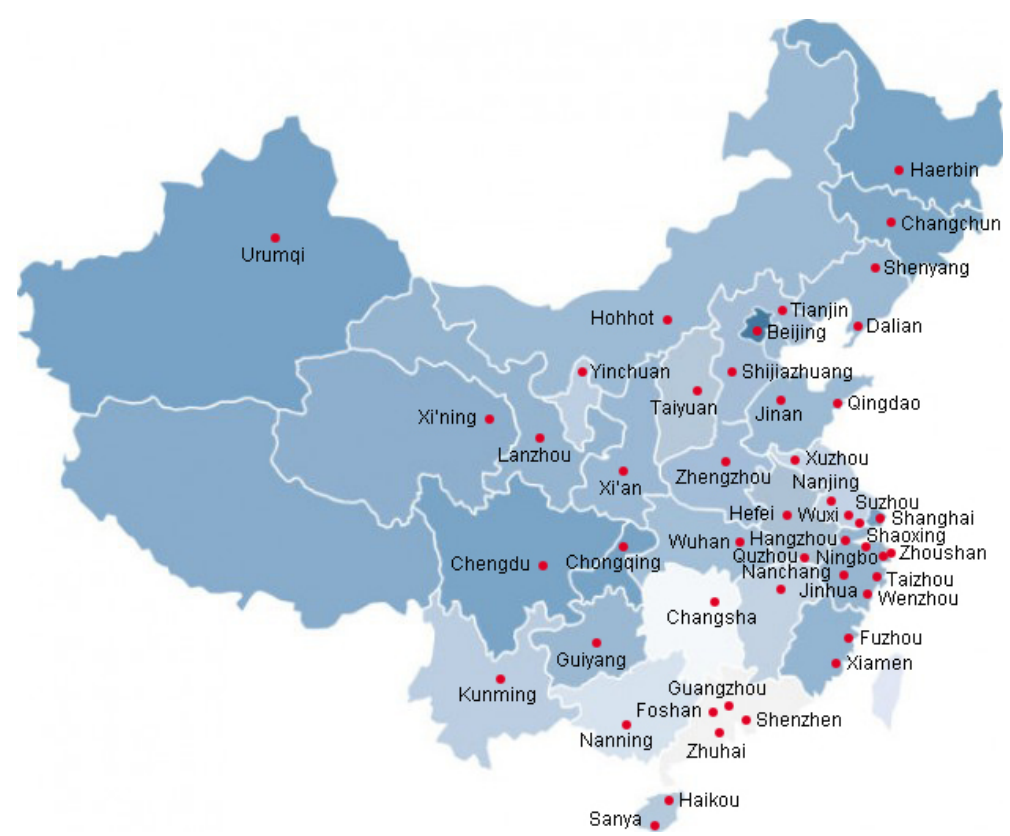

Fig 2 Locations of Restricted Cities

Table 8 Implementation of Housing Purchase Restriction Policies Across 97 Cities

\begin{tabular}{|c|c|c|c|c|c|}
\hline No & City & Starting Date & No & City & Starting Date \\
\hline 1 & Anshan & & 50 & Nanning & $17-02-2011$ \\
\hline 2 & Baotou & & 51 & Nantong & \\
\hline 3 & Baoding & & 52 & Ningbo & $11-10-2010$ \\
\hline 4 & Baoji & & 53 & Qinghuangdao & \\
\hline 5 & Beihai & & 54 & Qingdao & 31-01-2011 \\
\hline 6 & Beijing & $30-04-2010$ & 55 & Quanzhou & \\
\hline 7 & Changshu & & 56 & Rizhao & \\
\hline 8 & Changzhou & & 57 & Sanya & $17-10-2010$ \\
\hline 9 & Changchun & $20-05-2011$ & 58 & Shantou & \\
\hline 10 & Changsha & 5-03-2011 & 59 & Shaoxing & \\
\hline 11 & Chengdu & $16-02-2011$ & 60 & Shenzhen & $02-10-2010$ \\
\hline 12 & Dalian & $2-03-2011$ & 61 & Shenyang & 02-03-2011 \\
\hline 13 & Dezhou & & 62 & Shijiazhuang & 21-02-2011 \\
\hline
\end{tabular}




\begin{tabular}{|c|c|c|c|c|c|}
\hline 14 & Dongguan & & 63 & Suzhou & 03-03-2011 \\
\hline 15 & Eerduosi & & 64 & Suqian & \\
\hline 16 & Foshan & 19-03-2011 & 65 & Taizhou & \\
\hline 17 & Fuzhou & $11-10-2010$ & 66 & Taizhou & \\
\hline 18 & Ganzhou & & 67 & Taiyuan & $14-01-2011$ \\
\hline 19 & Guangzhou & $15-10-2010$ & 68 & Tangshan & \\
\hline 20 & Guilin & & 69 & Tianjin & $15-10-2010$ \\
\hline 21 & Guiyang & $18-02-2011$ & 70 & Weihai & \\
\hline 22 & Haerbin & 27-02-2011 & 71 & Tanfang & \\
\hline 23 & Haikou & $15-10-2010$ & 72 & Wenzhou & $18-10-2010$ \\
\hline 24 & Handan & & 73 & Wulumuqi & 11-03-2011 \\
\hline 25 & Hangzhou & $12-10-2010$ & 74 & Wuxi & $24-02-2011$ \\
\hline 26 & Heze & & 75 & Wuhu & \\
\hline 27 & Hefei & 25-01-2011 & 76 & Wujiang & \\
\hline 28 & Hengshui & & 77 & Wuhan & $15-01-2011$ \\
\hline 29 & Huhehaote & 14-04-2011 & 78 & Xian & 01-03-2011 \\
\hline 30 & Huzhou & & 79 & Xining & 02-08-2011 \\
\hline 31 & Huaian & & 80 & Xiamen & 08-10-2010 \\
\hline 32 & Huizhou & & 81 & Xiangtan & \\
\hline 33 & Jinan & 22-01-2011 & 82 & Xinxiang & \\
\hline 34 & Jiaxing & & 83 & Xuzhou & 01-05-2011 \\
\hline 35 & Jiangmen & & 84 & Yantai & \\
\hline 36 & Jiangyin & & 85 & Yangzhou & \\
\hline 37 & Jinhua & 23-07-2011 & 86 & Yichang & \\
\hline 38 & Kunming & 19-01-2011 & 87 & Yinchuan & 24-02-2011 \\
\hline 39 & Kunshan & & 88 & Yingkou & \\
\hline 40 & Lanzhou & 07-03-2011 & 89 & Zhanjiang & \\
\hline 41 & Langfang & & 90 & Zhangjiagang & \\
\hline 42 & Lianyungang & & 91 & Zhenjiang & \\
\hline
\end{tabular}




\begin{tabular}{|l|l|l|r|l|l|}
\hline 43 & Liaocheng & & 92 & Zhengzhou & 05-01-2011 \\
\hline 44 & Liuzhou & & 93 & Zhongshan & \\
\hline 45 & Luoyang & & 94 & Chongqing & \\
\hline 46 & Maanshan & & 95 & Zhuhai & 01-11-2011 \\
\hline 47 & Mianyang & & 96 & Zhuzhou & \\
\hline 48 & Nanchang & $23-02-2011$ & 97 & Zibo & \\
\hline 49 & Nanjing & $13-10-2010$ & & & \\
\hline
\end{tabular}

Note: The exact date that the policy was implemented according to the formal public document from the natural resources and building management board rather than from media coverage.

Table 9 Variables and Descriptions

\begin{tabular}{ll}
\hline Variables & Description \\
\hline
\end{tabular}

\section{Housing Market}

Average residential housing price: Real residential property price. Unit: RMB

Newly Residential housing price index: Property price index: newly constructed residential property. Unit: 2010m1=100

Second-hand residential housing price index: Property price index: secondary residential property. Unit: 2010m1=100

Small-size residential housing price index: Property price index: the size of residential property is smaller than 90 square meters.

Unit: $2010 \mathrm{~m} 1=100$

\section{Housing Transaction Market}

Transaction amount: The transaction amount of residential property. Unit: billion RMB

Transaction price: The transaction price of the residential property. Unit: RMB per square meter

Transaction floor: The transaction floor of the residential property. Unit: ten thousand square meters

Sales amount: Sales amount of newly constructed residential property. Unit: hundred million RMB

\section{Housing Investment and Construction Market}

Investment: Investment of residential property. Unit: hundred million

Floor under construction: Floor space under construction. Unit: ten thousand square meters

Floor started: Floor space started. Unit: ten thousand square meters

32.5 Concrete price: Price of the 32.5 concrete for housing renovation. Unit: RMB per ton

42.5 Concrete price: Price of the 42.5 concrete for housing construction. Unit: RMB per ton 
Table 10 Summary Statistics of Variables

\begin{tabular}{|c|c|c|c|c|c|}
\hline Variables & Mean & Std. Dev. & Min & Max & Median \\
\hline \multicolumn{6}{|l|}{ Housing Market } \\
\hline Average residential housing price & 8057.094 & 4329.712 & 2787 & 33000 & 6834 \\
\hline Newly built residential housing price index & 141.577 & 18.733 & 106.343 & 213.859 & 138.321 \\
\hline Second-hand residential housing price index & 127.767 & 27.080 & 0.000 & 183.379 & 127.435 \\
\hline Small-size residential housing price index & 107.285 & 20.459 & 0.000 & 138.640 & 108.723 \\
\hline \multicolumn{6}{|l|}{ Housing Transaction Market } \\
\hline Transaction amount & 76.974 & 64.639 & 1.498 & 411.140 & 63.300 \\
\hline Transaction price & 11000 & 6466.941 & 2441 & 30000 & 8589.500 \\
\hline Transaction floor & 61.222 & 47.013 & 0.000 & 240.520 & 50.590 \\
\hline Sales amount & 231.883 & 252.785 & 0.000 & 1561.130 & 138.239 \\
\hline \multicolumn{6}{|l|}{ Housing Investment and Construction Market } \\
\hline Investment & 328.534 & 364.282 & 0.000 & 2301.980 & 194.450 \\
\hline Floor under construction & 2777.815 & 1791.637 & 0.000 & 8482.490 & 2324.240 \\
\hline Floor started & 189.494 & 1214.808 & 0.000 & 6535.900 & 204.620 \\
\hline 32.5 Concrete price & 305.553 & 63.516 & 160 & 640 & 295 \\
\hline 42.5 Concrete price & 349.005 & 69.536 & 180 & 715 & 335 \\
\hline
\end{tabular}

Table 11 City Rank Based on Housing Prices in 2010

\begin{tabular}{|c|c|c|}
\hline City & Rank & $\begin{array}{c}\text { Average Residential Housing Price } \\
\text { (RMB per square meter) }\end{array}$ \\
\hline Hangzhou & 1 & 25840 \\
\hline Beijing & 2 & 22310 \\
\hline Shanghai & 3 & 19168 \\
\hline Wenzhou & 4 & 18854 \\
\hline Sanya & 5 & 16319 \\
\hline Shenzhen & 6 & 13438 \\
\hline Ningbo & 7 & 1878 \\
\hline
\end{tabular}




\begin{tabular}{|c|c|c|}
\hline Guangzhou & 8 & 12560 \\
\hline Nanjing & 9 & 12016 \\
\hline Zhoushan & 10 & 10500 \\
\hline Shaoxing & 11 & 10105 \\
\hline Zhuhai & 12 & 9747 \\
\hline Dalian & 13 & 9678 \\
\hline Xiamen & 14 & 9660 \\
\hline Suzhou & 15 & 9103 \\
\hline Taizhou & 16 & 8967 \\
\hline Qingdao & 17 & 8962 \\
\hline Tianjing & 18 & 8958 \\
\hline Nantong & 19 & 8950 \\
\hline Fuzhou & 20 & 8666 \\
\hline Huzhou & 21 & 8220 \\
\hline Haerbin & 22 & 7939 \\
\hline Wuxi & 23 & 7843 \\
\hline Foushan & 24 & 7822 \\
\hline Jinan & 25 & 7760 \\
\hline Quanzhou & 26 & 7680 \\
\hline Jiaxing & 27 & 7587 \\
\hline Haikou & 28 & 7288 \\
\hline Dongguan & 29 & 7023 \\
\hline Chengdu & 30 & 6630 \\
\hline Hefei & 31 & 6255 \\
\hline Er'erduosi & 32 & 6220 \\
\hline Wuhan & 33 & 6196 \\
\hline Nanning & 34 & 6137 \\
\hline Tangshan & 35 & 6098 \\
\hline Kunming & 36 & 6006 \\
\hline
\end{tabular}




\begin{tabular}{|c|c|c|}
\hline Jinhua & 37 & 6000 \\
\hline Zhongshan & 38 & 5988 \\
\hline Yantai & 39 & 5835 \\
\hline Chongqing & 40 & 5720 \\
\hline Rizhao & 41 & 5700 \\
\hline Zhengzhou & 42 & 5689 \\
\hline Huizhou & 43 & 5649 \\
\hline Yichang & 44 & 5637 \\
\hline Taiyuan & 45 & 5635 \\
\hline Yangzhou & 46 & 5630 \\
\hline Nanchang & 47 & 5573 \\
\hline Changchun & 48 & 5445 \\
\hline Lanzhou & 49 & 5440 \\
\hline Xian & 50 & 5398 \\
\hline Weihai & 51 & 5363 \\
\hline Changsha & 52 & 5339 \\
\hline Changzhou & 53 & 5302 \\
\hline Jiangmen & 54 & 5205 \\
\hline Anshan & 55 & 5150 \\
\hline Qinghuangdao & 56 & 5114 \\
\hline Zhangzhou & 57 & 5110 \\
\hline Tai'an & 58 & 5100 \\
\hline Langfang & 59 & 5090 \\
\hline Zhenjiang & 60 & 5052 \\
\hline Chengde & 61 & 5016 \\
\hline Shenyang & 62 & 4980 \\
\hline Huhehaote & 63 & 4920 \\
\hline Shijiazhuang & 64 & 4874 \\
\hline Guilin & 65 & 4865 \\
\hline
\end{tabular}




\begin{tabular}{|c|c|c|}
\hline Taizhou & 66 & 4830 \\
\hline Niuzhou & 67 & 4822 \\
\hline Daqing & 68 & 4814 \\
\hline Zhanjiang & 69 & 4772 \\
\hline Jiujiang & 70 & 4771 \\
\hline Yinchuan & 71 & 4690 \\
\hline Xuzhou & 72 & 4632 \\
\hline Lianyungang & 73 & 4610 \\
\hline Guiyang & 74 & 4534 \\
\hline Wulumuqi & 75 & 4410 \\
\hline Dongying & 76 & 4370 \\
\hline Shantou & 77 & 4330 \\
\hline Handan & 78 & 4300 \\
\hline Baotou & 79 & 4225 \\
\hline Luoyang & 80 & 4207 \\
\hline Yancheng & 81 & 4150 \\
\hline Yan'an & 82 & 4135 \\
\hline Jilin & 83 & 4008 \\
\hline Jining & 84 & 3950 \\
\hline Beihai & 85 & 3890 \\
\hline Kaifeng & 86 & 3737 \\
\hline Huludao & 87 & 3719 \\
\hline Weifang & 88 & 3689 \\
\hline Qiqi'haer & 89 & 3671 \\
\hline Qingyuan & 90 & 3625 \\
\hline Yingkou & 91 & 3580 \\
\hline Jingzhou & 92 & 3550 \\
\hline Xining & 93 & 3440 \\
\hline Xiangfan & 94 & 3432 \\
\hline
\end{tabular}




\begin{tabular}{|c|c|c|}
\hline Lasa & 95 & 3400 \\
\hline Zibo & 96 & 3300 \\
\hline Dandong & 97 & 3273 \\
\hline Kashi & 98 & 3250 \\
\hline Zhangjiakou & 99 & 3210 \\
\hline Kelamayi & 100 & 3200 \\
\hline
\end{tabular}

Data source: China City Statistical Yearbook in 2010 